\title{
Evaluation of the effect of natural peptide 'Urocortin' on corticotrophin releasing factor (CRF) receptor expression in ND7/23 cells
}

\author{
Omair Anwar Mohiuddin ${ }^{1, *}$, Chris Biggs ${ }^{2}$ \\ ${ }^{1}$ Department of Pharmaceutics, Dow College of Pharmacy, Dow University of Health sciences, Karachi, Pakistan, \\ ${ }^{2}$ School of Biosciences, University of Westminster, London, UK
}

\begin{abstract}
CRF receptors are involved in the stress management of the cells and are believed to have a cytoprotective role in the body. CRF receptors have been reported to be potential drug targets for the treatment of neurodegenerative disorders. The cell line used in the study is ND7/23 (mouse neuroblastoma and rat dorsal root ganglion neuron hybridoma). The aim of the study was to confirm the expression of CRF receptors in ND7/23 cells and to determine if urocortin (Ucn) can enhance the expression of CRF receptors. ND7/23 cells were cultured in RPMI 1640 media and cells grown after the second passage were used for the experiments. RNA was extracted from the cells and amplified by RT-PCR to confirm the presence of CRF receptors. The cells were then subjected to oxidative stress by hydrogen peroxide $(0.00375 \%)$ and divided into two groups i.e. control and $\operatorname{Ucn}\left(10^{-8} \mu \mathrm{M}\right)$ treated. Later RNA was extracted from both group of cells and PCR was performed. Finally, densitometry analysis was conducted on the agarose gel to determine the quantity of PCR product formed. PCR experiment confirmed the expression of both CRF-R1 and CRF-R2 in the cell line, but CRF-R1 was found to be expressed more strongly. Densitometry analysis of the PCR product and calculation of the relative expression of CRF receptors indicated a higher level of expression of CRF receptors in samples treated with Ucn as compared to those that were kept untreated. The results indicate that Ucn may be useful for the management of neurodegenerative disorders and further studies may be carried out to establish its use as a therapeutic agent.
\end{abstract}

Uniterms: Urocortin. ND7/23 cells. Corticotrophin releasing factor. RT-PCR. Neuronal cells.

Receptores de CRF estão envolvidos na gestão do estresse das células e são acreditados para ter um papel de cito-proteção no organismo. Os receptores do CRF têm sido relatados como alvos potenciais de fármacos para o tratamento de doenças neurodegenerativas. A linhagem celular utilizada no estudo é ND7/23 (neuroblastoma de camundongo e hibridoma de raíz dorsal do neurônio ganglionar de rato). O objetivo do estudo foi confirmar o que a expressão de receptores de CRF em células ND7/23 determinar se urocortina (Ucn) pode aumentar a expressão de receptores de CRF. Cultivaram-se células ND7/23 em meio RPMI 1640 e as células que cresceram após a segunda passagem foram usadas para os experimentos. O RNA foi extraído células e amplificado por RT-PCR para confirmar a presença de receptores de CRF. As células foram, então, submetidas a estresse oxidativo por peróxido de hidrogênio $(0.00375 \%)$ e divididas em dois grupos, ou seja, controle e tratadas com UCN $\left(10^{-8} \mu \mathrm{M}\right)$. Em seguida, o RNA foi extraído de ambos os grupo de células e realizou-se o PCR. Finalmente, realizou-se análise densitométrica em gel de agarose para determinar a quantidade de produto formado por PCR. O PCR confirmou a expressão de CRF-R1 e CRF-R2 na linhagem celular, mas o CRF-R1 expresso mais fortemente. A análise densitométrica do produto de PCR e o cálculo da expressão relativa de receptores de CRF indicaram um nível mais elevado de expressão de receptores de CRF em amostras tratadas com Ucn, em comparação com aqueles sem tratamento. Os resultados indicam que a Ucn pode ser útil no tratamento de doenças neurodegenerativas e mais estudos podem ser realizados para estabelecer seu uso como agente terapêutico.

Unitermos: Doenças neurodegenerativas/tratamento. Urocortina . Células ND7/23. RT-PCR. Células neuronais.

\footnotetext{
*Correspondence: Omair Anwar Mohiuddin. Dow college of Pharmacy, Dow University of Health Sciences, Gulzar-e-Hijri, Suparco road, KDA scheme 33, Karachi, Pakistan. E-mail: omair.anwar@duhs.edu.pk
} 


\section{INTRODUCTION}

Corticotrophin releasing factor (CRF) was first discovered in 1981 and was found to be a regulator of the endocrine stress response (Bale, Wale, 2004). CRF receptors are members of G-protein coupled receptor (GPCR) family. The two main subtypes of CRF receptors are CRF receptor 1 (CRF-R1) and CRF receptor 2 (CRF-R2), which are products of two separate genes (Roloff et al., 1998). These receptors have various splice variants that are expressed in both tissues of central and peripheral region, with CRF-R2 existing as $\alpha$ and $\beta$ isoforms (Grigoriadis, 2001). Based on amino acid sequences, CRF-R1 and CRF-R2 have almost $70 \%$ homology, and only differ at one end of the amino acid sequence (Bale, Wale, 2004).

CRF is a vital regulator of endocrine response to stress (Meaney et al., 1996); it is found in the region of paraventricular nucleus (PVN) of the hypothalamus, central nucleus of amygdala and hindbrain regions of the CNS (Qiu et al., 2005). It is also found in peripheral regions, such as gut, skin and adrenal gland (Bale, Wale, 2004). CRF-R1 has been reported to be responsible for the stress response on the cellular level, whereas the role of CRF-R2 in stress response has not been clearly established yet (Qiu et al., 2005).

In the current study, the cell line used was ND7/23, which is a hybrid of mouse neuroblastoma (N18 tg 2) and rat dorsal root ganglion neuron, produced by PEG mediated cell fusion (Herold et al., 2009). ND7/23 cells had not been used for studies related to CRF receptors before. Therefore, there were no details available for the expression of CRF receptors in this cell line. The aim of this study was to detect if CRF receptors are expressed in ND7/23 cells.

Urocortin (Ucn) is a naturally occurring hormone, which has been identified as a natural analogue of CRF and a neuroprotective agent (Abuirmeileh et al., 2007). Ucn is a peptide comprising of 40 amino acids and it belongs to CRF peptide family, functioning via corticotrophin releasing factor receptors (CRFR) (Wang et al., 2008). Ucn has been found to have affinity for both CRFR1 and CRFR2 (Tezval et al., 2009). The possible cyto-protective role of Ucn has been suggested by many previous studies for cardiac myocytes (Brar et al., 2000). The optimum dose of Ucn to exert a protective effect for cardiac myocytes has been determined to be $10^{-8} \mathrm{M}$ (Brar et al., 2002).

Mouse CRF-R1 protein has 97\% homology with human CRF-R1 protein, whereas mouse CRF-R2 protein has $92 \%$ homology with human CRF-R2 protein. Mouse Ucn has around $79 \%$ similarity with human Ucn (Sequence homologies determined using NCBI/BLAST online). These observations were significant for the study since mouse cells were being used. High sequence homologies between mouse and human CRF-R1 and CRF-R2 protein and Ucn ensured that human CRF-R1 and CRF-R2 primers should provide appropriate PCR product. High sequence homologies also mean that the results can be applied to studies involving human models as well in the future (Kwitek et al., 2001).

Different neuro-degenerative disorders like Parkinson's disease (PD) are caused due to the loss of neurons (Chinta et al., 2007). Originally, it was postulated that the cell death is caused by apoptosis, excitotoxic events or free radical production (Gandhi, Wood, 2005). More recently, it has been suggested that pre- and postnatal neuroinflammation might be a cause of neuronal disorders (Block, Zecca, Hong, 2007). Therefore, protection of neuronal cells using Ucn can be extremely useful for untreatable neuronal disorders (Martin et al., 2007). The latest efforts to treat such disorders have been focused on the neuronal level by protecting the neurons from apoptosis (Sredni et al., 2007). The main aim of the study was to explore more about the neuro-protective role of Ucn in cells subjected to oxidative stress by hydrogen peroxide. The results obtained from the current study can help establish the use of Ucn for the treatment of neurodegenerative disorders.

\section{MATERIAL AND METHODS}

\section{Cell culture}

The cell line used for the experiments was ND7/23 rat dorsal root ganglia/mouse neuro-blastoma hybrid (acquired from ECACC). Frozen cells were thawed and then spun down in a centrifuge at $1500 \mathrm{rpm}$, supernatant was discarded and cells were re-suspended into RPMI1640 medium in $15 \mathrm{~mL}$ flasks. Flasks were then incubated for a few days in humidified incubator at $37{ }^{\circ} \mathrm{C}$ and $5 \%$ $\mathrm{CO}_{2}$ (Oliveira et al., 2010). For the second passage DPBS (Dulbecco's phosphate buffered saline) was added to the flasks, cells were centrifuged and transferred to further flasks along with fresh RPMI 1640 media.

\section{MTT assay}

Toxicity of Ucn and hydrogen peroxide was determined using MTT assay, in order to identify the optimum therapeutic dose of Ucn and optimum sub-lethal dose of hydrogen peroxide for the experiments. To perform MTT assay 96 well plate format was used. 8 wells each, in four rows of the plate was filled with $100 \mu \mathrm{L}$ of cell suspension containing ND7/23 cells suspended in RPMI- 
1640. The plate was left overnight in the incubator, to allow cells to grow. Next day the cells in the 96 wells plate were subjected to different concentrations of hydrogen peroxide, to induce oxidative stress and apoptosis. First well in each of the four rows was kept as control and then the next six wells were added with six different concentrations of hydrogen peroxide, which were $0.0018 \%, 0.00375 \%, 0.0075 \%$, $0.015 \%, 0.03 \%$ and $0.06 \%$.

Another 96 well plate was also set up, where the wells were again filled with $100 \mu 1$ of cell suspension and left over night in the incubator. In each of the first four rows of the plate, the first well was kept as control and cells in the next six wells were treated with increasing concentration of Ucn, which were $1 \times 10^{-8} \mathrm{M}, 2 \times 10^{-8} \mathrm{M}$, $4 \times 10^{-8} \mathrm{M}, 1 \times 10^{-7} \mathrm{M}, 2 \times 10^{-7} \mathrm{M}$ and $4 \times 10^{-7} \mathrm{M}$.

\section{RNA extraction}

RNA extraction was carried out using the protocol mentioned by Chomczynski and Mackey (1995). Cultured cells from each flask were centrifuged, all cells were then homogenized with trizol and transferred to sterile Eppendorf tubes and centrifuged again. RNA pellet in the form of a faint smear appeared at the bottom of the tubes at the end of the process. The supernatant was removed carefully and $1 \mathrm{~mL}$ of $75 \%$ ethanol was added to the tubes for desalting of the pellet and the samples were again centrifuged. Eppendorf concentrator (model 5301) was used to dry the RNA pellets. After drying the pellets, they were re-dissolved in $50 \mu \mathrm{L}$ of diethylpyrocarbonate (DEPC) water.

\section{Treatment of cells with hydrogen peroxide and Ucn}

ND7/23 cells were cultured in four flasks and allowed to grow to adequate quantity. The cells in the first flask were used as control i.e. untreated (sample A). Cells in second flask were treated with $1 \times 10^{-8} \mathrm{M}$ Ucn (sample B). The third flask contained cells treated with $0.00375 \%$ (optimum sub-lethal concentration) hydrogen peroxide (sample C). In the fourth flask, cells were treated with both $0.00375 \%$ (sub-lethal concentration) hydrogen peroxide and $1 \times 10^{-8} \mathrm{M} \mathrm{Ucn}$ (sample D). After 24 hours of incubation of all the mentioned cell samples, RNA extraction was performed.

\section{PCR of RNA extracted from control and treated cell samples}

The extracted RNA was subjected to PCR using rat CRFR primers. Since the extracted samples contained
RNA, therefore, reverse transcriptase PCR (RT-PCR) was performed to identify expression of CRF receptors, for that purpose, Qiagen ${ }^{\circledR}$ one step PCR kit was used.

RNA extracted from cell samples A, B, C and D were amplified by PCR and the same PCR protocol as mentioned earlier was utilized. First PCR was performed on sample A and B, where extracted RNA from both samples were mixed with each CRF-R1 primer, CRF-R2 primer, GAPDH primer (housekeeping gene) and KIR 6.1 primer (since Ucn is considered to function through potassium channel) in separate tubes and PCR was carried out. Second PCR was performed for samples treated with $0.00375 \%$ hydrogen peroxide with and without Ucn (sample C and D). Both samples were mixed separately with each primer i.e. CRF-R1, CRF-R2, GAPDH and KIR 6.1 and PCR was performed.

The primer sequences of all the primers used to perform PCR are as follows.

\section{Rat CRF-R1 primer:}

Forward primer: 5' ACAAACAATGGCTACCGGGA 3' Reverse primer: 5' TCATGGGGCCCTGGTAGAT 3'

\section{Rat CRF-R2 primer:}

Forward primer: 5' TGTGGAAGGCTGCTACCTG 3'

Reverse primer: 5' GTGTGCTTGATGCTGTGGAA 3'

\section{GAPDH primer:}

Forward primer: 5' CATCATCTCTGCCCCCTCTG 3' Reverse primer: 5' CCTGCTTCACCACCTTCTTG 3'

KIR primer:

Forward primer: 5' GCTTTGTGTCCATTGTGACTG 3' Reverse primer: 5' GCTGTCATGATTCCGATGTG 3'

\section{Gel electrophoresis}

$2 \%$ agarose gel was prepared by dissolving $2 \mathrm{~g}$ agarose in $100 \mathrm{~mL}$ TBE buffer. Gel electrophoresis was performed using savant PS250 power pack for 60 minutes at $105 \mathrm{~V}$. The PCR products from control and treated cell samples were also run on an agarose gel and visualized in UVipro light box visualizer; using UVtec gel analysis software (Figures III and IV).

\section{Densitometric analysis}

After all the PCRs were performed and products run on gel, gel densitometric analysis was performed to analyze the band size using UVtec gel analysis software. The same method as used by Pachner and Ricalton (1992) was utilized 
for densitometric analysis. The band sizes provided an approximate idea of the amount of PCR product formed. The amount of product formed gave an estimate of the extent of receptor expression (Tables I and II).

\section{CRF receptor expression}

For the determination of relative expression of CRF receptors to GAPDH gene, the ratio of band areas (determined by densitometry) of GAPDH gene (PCR product) to CRF receptor gene (PCR product) were calculated for respective cell samples (untreated and treated with Ucn).

\section{RESULTS AND DISCUSSION}

ND7/23 cells exhibited slow growth during the first passage, whereas growth was much better in later passages. Over all ND7/23 cells displayed very good growth in RPMI 1640 media within 3-4 days.

MTT assay performed on cells treated with Ucn was used to determine cell viability. Mean values of percentage cell survival for 4 wells of each concentration of Ucn and hydrogen peroxide have been plotted in Figure 1 and 2, respectively. The percentage cell survival of each sample was calculated relative to the absorbance of control well. The figure shows that maximum cell viability is observed when cells were treated with Ucn at $1 \times 10^{-8} \mu \mathrm{M}$ dose, which is in accordance with the concentration by Brat et al. (2000), in the case of cardiac myocytes. Hence, this dose was used for all proceeding experiments.

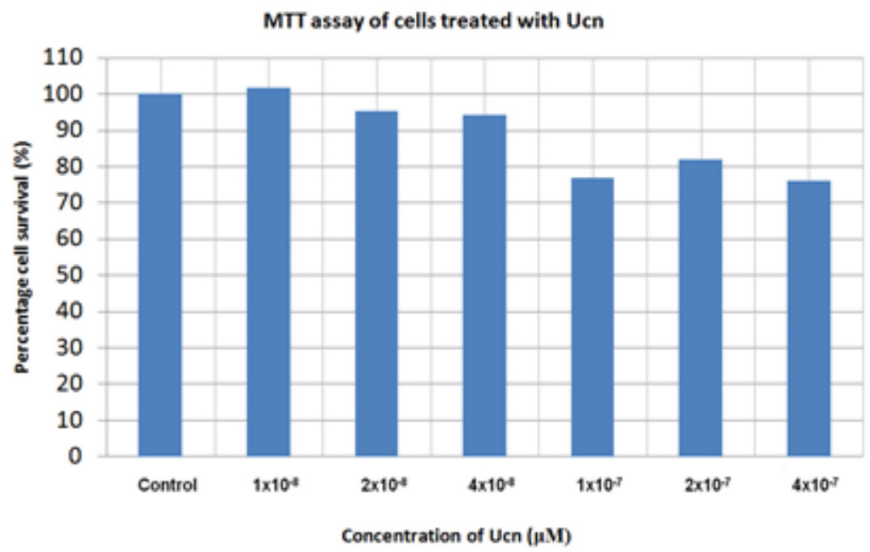

FIGURE 1 - Effect of different concentrations of Ucn on ND7/23 cells survival.

Second MTT assay was performed to determine sub-lethal dose of hydrogen peroxide that could be used to induce oxidative stress to cells without causing complete cell death. $0.00375 \%$ hydrogen peroxide was found to cause significant stress to the cells and was therefore was chosen for all proceeding experiments.

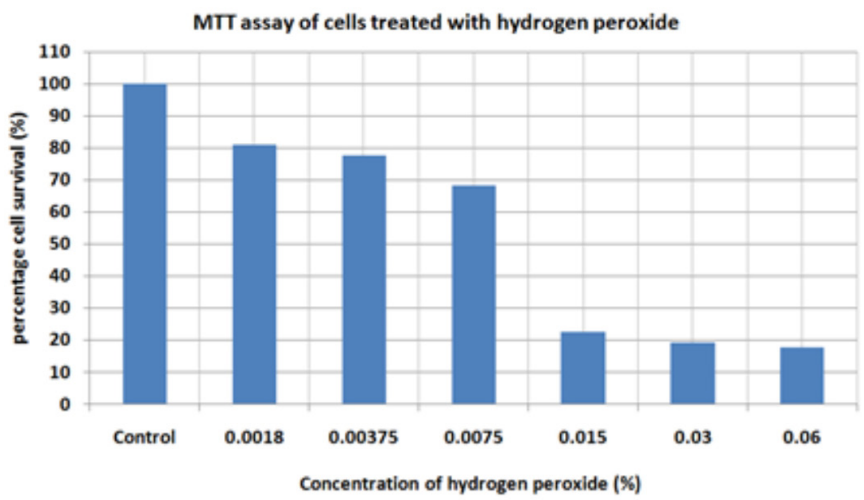

FIGURE 2 - Effect of different concentrations of hydrogen peroxide on ND7/23 cells survival.

In Figure 3 clear bands are visible in lane 2 and 3 that contain PCR products of control and GAPDH primer, but the band in lane 3 appears to be brighter than the band in lane 2. Lane 3 contained the PCR product of RNA sample from cells treated with Ucn. Clear bands are visible in lane 4 and 5, which contained PCR product of CRF-R1 primer and controls; here as well the PCR product of RNA sample extracted from cells treated with Ucn is brighter than the

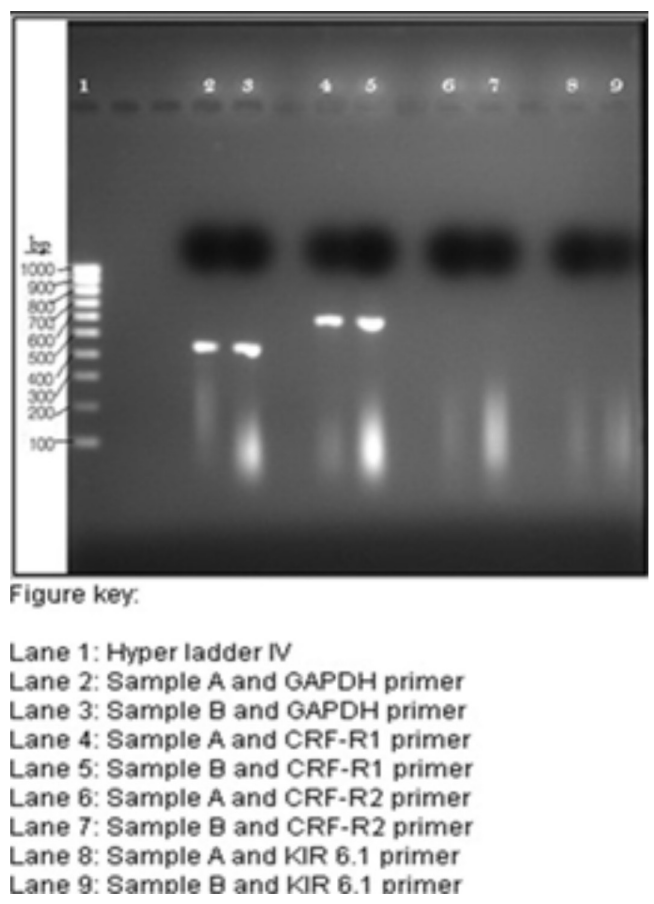

FIGURE 3 - Agarose gel photograph showing PCR product of Controls with GAPDH primer, CRF-R1 primer, CRF-R2 primer and KIR 6.1 primer. 
one not treated with Ucn. No bands are visible in lanes 6 to 9; therefore, it can believed that no PCR product was formed with CRF-R2 and KIR6.1 primers, which could have been due to non-homologous primers, improper reaction conditions or that the cells do not express the genes at all. Visually it is evident that samples treated with Ucn resulted in brighter bands.

In Figure 4 clear bands are visible in lane 2 and 3 that contained PCR products of GAPDH primer and controls. The band in lane 3 is considerably brighter than the band in lane 2. Lane 3 contained PCR product of RNA sample extracted from the cell sample treated with Ucn. Clear band is visible in lane 5 that contains PCR product of RNA sample from cells treated with Ucn and CRF-R1 primer. A faint band is visible in lane 4 which contained RNA extracted from the cell sample that was not treated with Ucn. Lane 6 and 7 contained PCR products with CRF-R2 primers and a band is only visible in lane 7 that contained RNA sample extracted from cell sample treated with Ucn. No bands are visible in lane 8 and 9 that contained PCR products with KIR6.1 primer, which could have been due to reasons as discussed earlier.

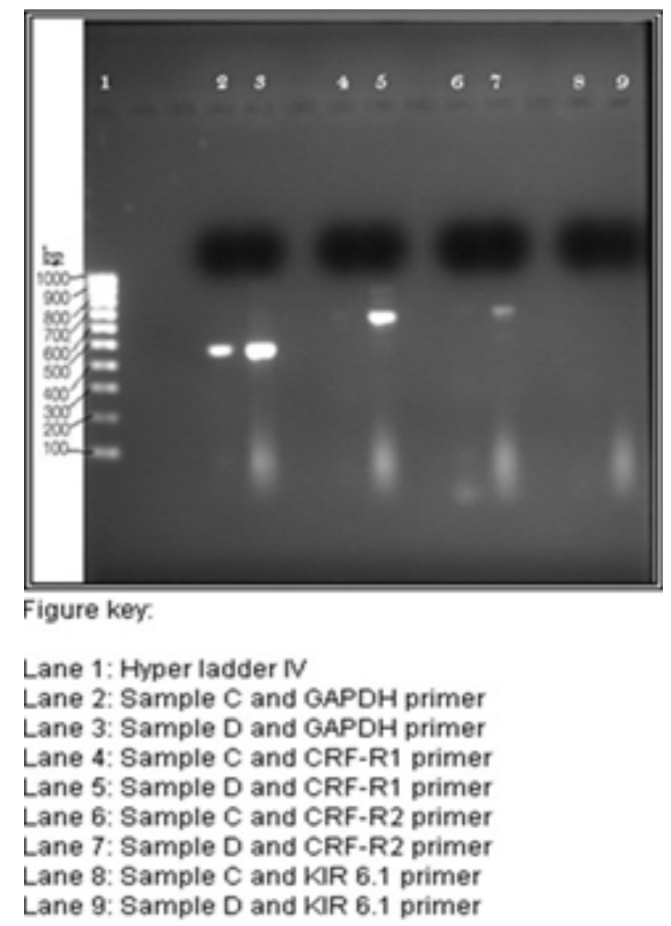

FIGURE 4 - Agarose gel photograph showing PCR products of samples treated with $0.00375 \% \mathrm{H}_{2} \mathrm{O}_{2}$ with GAPDH, CRF-R1 primer, CRF-R2 primer and KIR 6.1 primer.

Densitometry analysis (Table I and II) was performed to determine the band area of PCR product obtained on the gel. The band area of CRFR primers was compared with the band area produced by the housekeeping gene, which was GAPDH. Relative expression of CRF receptor to GAPDH was calculated using the values obtained by densitometry. Calculation of relative expression (Table III) of the CRF receptors to GAPDH products clearly indicates a higher level of expressions of CRF-R1 and CRF-R2 in samples treated with Ucn as compared to those, which were not treated with Ucn.

TABLE I - Showing band areas by densitometry analysis of Figure 3

\begin{tabular}{cc}
\hline BAND & BAND AREA \\
\hline Lane 2 & 654 \\
Lane 4 & 701 \\
Lane 3 & 804 \\
Lane 5 & 889 \\
\hline
\end{tabular}

Note: band area is mentioned in arbitrary units

TABLE II - Showing band areas by densitometric analysis of Figure 4

\begin{tabular}{cc}
\hline BAND & BAND AREA \\
\hline Lane 2 & 649 \\
lane 3 & 989 \\
Lane 4 & Too small to calculate \\
Lane 5 & 868 \\
Lane 7 & 693 \\
\hline
\end{tabular}

Note: band area is mentioned in arbitrary units

TABLE III - Relative expression of CRF receptors to GAPDH receptor in all cell samples

\begin{tabular}{lc}
\hline Sample & Relative expression \\
\hline A + CRFR1 primer (untreated) & 1.07 \\
B + CRFR1 primer (treated with Ucn) & 1.10 \\
C + CRFR1 primer (untreated) & 0.00 \\
D + CRFR1 primer (treated with Ucn) & 0.0877 \\
C + CRFR2 primer (untreated) & 0.00 \\
D + CRFR2 primer (treated with Ucn) & 0.7 \\
\hline
\end{tabular}

The current study has established the presence and expression of both CRF receptors in ND7/23 cell line, but the results also clearly suggest that CRF-R1 is expressed in much greater quantity as compared to CRF-R2. It has been confirmed by previous studies that Ucn binds to CRF-R2 (Bale, Wale, 2004), but unlike CRF-R1, its effect on cell survival when working via CRF-R2 has not yet been 
established (Sawada, Fukui, Hawkes, 2008). Therefore, greater expression of CRF-R1 certainly increase the chance of attaining more cell viability after treatment, but further experiments need to be conducted to confirm this phenomenon. The first indication of higher expression of CRF receptors in both figures was the brightness of the bands obtained from PCR products of all samples pre-treated with Ucn and the later calculations confirmed the hypothesis. Since it is known that Uen binds to CRF receptors, and all other components in each sample treated with Ucn were same as in samples not treated with Ucn; thus the presence of higher amount of CRF receptor protein in the cell samples indicates that Ucn has upregulated the CRF gene. The increased amount of CRF receptor protein in samples could be either because of an increased expression or the presence of higher number of viable cells. The PCR product of GAPDH gene from cell sample treated with Ucn is brighter as compared to untreated sample, which could have been due to increased survival of cells in samples treated with Ucn.

Gene expression experiment was performed as a unique experiment due to lack of funds and for future studies it would be more useful if the experiment could be replicated to further confirm the results.

\section{CONCLUSION}

The results obtained from PCR confirmed that ND7/23 cells express CRF-R1 and CRF-R2. CRF-R1 was found to be expressed more strongly as compared to CRF-R2. The results obtained from experiments showing increased concentration of RNA in samples treated with Ucn are suggestive that treatment of cells with Ucn has positive effect on CRF receptor expression. Amongst the PCR products, higher expression of CRF receptors was observed in samples that were treated with Ucn. From the set of experiments performed in this study there is evidence to suggest that Ucn has up regulated CRF receptors. Since CRF receptors are involved in the stress management of cells in the body, therefore increased expression of CRFR should increase the survival of cells by protecting against oxidative stress. The results obtained would be helpful in determining the use of Ucn for the treatment of neurodegenerative disorders like PD.

\section{ACKNOWLEDGMENTS}

The authors would like to thank the School of Biosciences at University of Westminster for providing technical support throughout the study.

\section{REFERENCES}

ABUIRMEILEH, A.; HARKAVYI, A.; LEVER, R.; BIGGS C. S.; WHITTON, P. S. Urocortin, a CRF-like peptide, restores key indicators of damage in the substantia nigra in a neuroinflammatory model of Parkinson's disease. $J$. Neuroinflamm., v.4, n.19, p.1-5, 2007.

BALE, T. L.; WALE, W. W. CRF and CRF receptors: role in stress responsivity and other behaviors. Annu. Rev. Pharmacol. Toxicol., v.44, p.525-527, 2004.

BLOCK, M. L.; ZECCA, L.; HONG, J. S. Microglia-mediated neurotoxicity: uncovering the molecular mechanism. Nat. Rev. Neurosci., v.8, n.1, p.57-69, 2007.

BRAR, B. K.; JONASSEN, A. K.; STEPHANOU, A.; SANTILLI, G.; RAILSON, J.; KNIGHT, R. A.; YELLON, D. M.; LATCHMAN, D. S. Urocortin protects against ischemic and reperfusion injury via a MAPK-dependant pathway. J. Biol. Chem., v.275, n.12, p.8508-8514, 2000.

BRAR, B.K.; RAILSON, J.; STEPHANOU, A.; KNIGHT, R. A.; LATCHMAN, D. S. Urocortin increases the expression of heat shock protein 90 in rat cardiac myocytes in a MEK1/2-dependent manner. J. Endocrinol., v.172, n.2, p.283-293, 2002.

CHINTA, S. J.; KUMAR, M. J.; HSU, M.; RAJAGOPALAN, S.; KAUR, D.; RANE, A.; NICHOLLS, D. G.; CHOI, J.; ANDERSEN, J. K.Inducible alterations of glutathione levels in adult dopaminergic midbrain neurons result in nigrostriatal degeneration. J. Neurosci., v.27, n.51, p.1399714006, 2007.

CHOMCZYNSKI, P.; MACKEY, K. Modification of the TRI reagent ${ }^{\mathrm{TM}}$ procedure for isolation of RNA from polysaccharide - and proteoglycan - rich sources. Biotechniques, v.19, n.6, p.942-945, 1995.

GANDHI, S.; WOOD, N. W. Molecular pathogenesis of Parkinson's disease. Hum. Mol. Genet., v.14, n.2, p.27492755, 2005.

GRIGORIADIS, D. E.; HADDACH, M.; LING, N.; SAUNDERS, J. The CRF receptor structure, function and potential for therapeutic intervention. Curr. Med. Chem.: Cent. Nerv. Syst. Agents, v.1, n.1, p.63-97, 2001. 
HEROLD, K. F.; NAU, C.; OUYANG, W.; HEMMINGS Jr., H.C. Isoflurane inhibits the tetrodotoxin-resistant voltagegated sodium channel Nav1.8. Anesthesiology, v.111, n.3, p.591-599, 2009.

KWITEK, A. E.; TONELLATO, P. J.; CHEN, D.; HANDLEY, J. G.; CHENG, Y. S.; TWIGGER, S.; SCHEETZ ,T. E.; CASAVANT, T. L.; STOLL, M.; NOBREGA, M. A.; SHIOZAWA, M.; SOARES, M. B.; SHEFFIELD, V. C.; JACOB, H. J. Automated construction of high-density comparative maps between rat, human, and mouse. Genome Res., v.11, n.11, p.1935-1943, 2001.

MARTIN, B.; LOPEZ DE MATURANA, R.; BRENNEMAN, R.; WALENT, T.; MATTSON, M. P.; MAUDSLEY, S. Class II G protein-coupled receptors and their ligands in neuronal function and protection. Neuromol. Med., v.7, n.1/2, p.3-36, 2005.

MEANEY, M. J.; DIORIO, J.; FRANCIS, D.; WIDDOWSON, J.; LaPLANTE, P.; CALDJI, C.; SHARMA, S.; SECKL, J. R.; PLOTSKY, P. M. Early environmental regulation of forebrain glucocorticoid receptor gene expression: implications for adrenocortical responses to stress. Dev. Neurosci., v.18, n.1/2, p.49-72, 1996.

OLIVEIRA, H.; PIRES, L. R.; FERNANDEZ, R.; MARTINS, M. C.; SIMÕES, S.; PÊGO, A. P. Chitosan-based gene delivery vectors targeted to the peripheral nervous system. J. Biomed. Mater. Res. A, v.95, n.3, p.801-810, 2010.

PACHNER, A. R.; RICALTON, N. S. Western blotting in evaluating Lyme seropositivity and the utility of a gel densitometric approach. Neurology, v.42, n.11, p.2185$2192,1992$.

QIU, D. L.; CHU, C. P.; SHIRASAKA, T.; TSUKINO, H.; NAKAO, H.; KATO, K.; KUNITAKE, T.; KATOH, T.; KANNAN, H.Corticotrophin-releasing factor augments the $\mathrm{I}_{\mathrm{H}}$ in rat hypothalamic paraventricular nucleus parvocellular neurons in vitro. J. Neurophysiol., v.94, n.1, p.226-234, 2005 .
ROLOFF, B.; FECHNER, K.; SLOMINSKI, A.; FURKERT, J.; BOTCHKAREV, V. A.; BULFONE-PAUS, S., ZIPPER, J.; KRAUSE, E.; PAUS, R. Hair cycle-dependent expression of corticotrophin-releasing factor (CRF) and CRF receptors in murine skin. FASEB J., v.12, n.3, p.287-297, 1998.

SAWADA, K.; FUKUI, Y.; HAWKES, R. Spatial distribution of corticotrophin-releasing factor immunopositive climbing fibers in the mouse cerebellum: analysis by whole mount immunohistochemistry. Brain Res., v.1222, p.106-117, 2008.

SREDNI, B.; GEFFEN-ARICHA, R.; DUAN, W.; ALBECK, M.; SHALIT, F.; LANDER, H. M.; KINOR, N.; SAGI, O.; ALBECK, A.; YOSEF, S.; BRODSKY, M.; SREDNIKENIGSBUCH, D.; SONINO, T.; LONGO, D. L.; MATTSON, M. P.; YADID, G. Multifunctional tellurium molecule protects and restores dopaminergic neurons in Parkinson's disease models. FASEB J., v.21, n.8, p.18701883, 2007.

TEZVAL, H.; JURK, S.; ATSCHEKZEI, F.; BECKER, J. U.; JAHN, O.; SERTH, J.; KUCZYK, M.A. Urocortin and corticotropin-releasing factor receptor 2 in human renal cell carcinoma: disruption of an endogenous inhibitor of angiogenesis and proliferation. World J. Urol., v.27, n.6, p.825-830, 2009.

WANG, J.; XU, Y.; XU, Y.; ZHU, H.; ZHANG, R.; ZHANG, G.; LI, S. Urocortin's inhibition of tumor growth and angiogenesis in hepatocellular carcinoma via corticotrophinreleasing factor receptor 2. Cancer Invest., v.26, n.4, p.359$368,2008$.

Received for publication on $13^{\text {th }}$ December 2013 Accepted for publication on $11^{\text {th }}$ April 2014 
